San Antonio Review • San Antonio Review (Volume III | Summer 2020)

\title{
White Kids: A Review
}

Peter Berard ${ }^{1}$

${ }^{1}$ San Antonio Review

Published on: Jul 21, 2020

DOI: $10.21428 / 9 b 43 c d 98 . d 6722507$

License: Creative Commons Attribution 4.0 International License (CC-BY 4.0). 


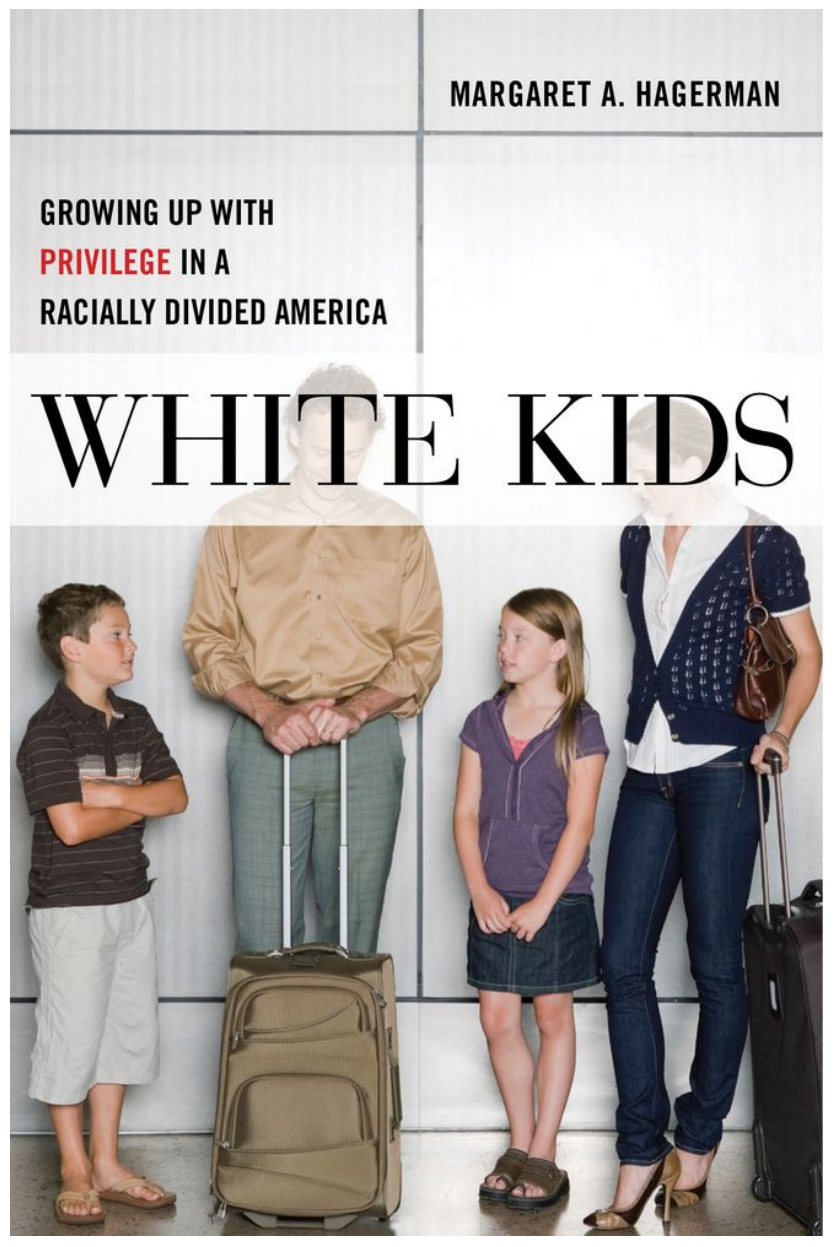

Book Reviewed:

White Kids: Growing Up With Privilege in a Racially Divided $\underline{\text { America }}$

Margaret A. Hagerman

NYU Press, 2018 280 pages

Margaret Hagerman spent years in the wilds of privileged white America, talking with kids, going to their soccer games, etc. in order to produce White Kids: Growing Up With Privilege in a Racially Divided America. Working in the Midwestern burg of "Peterfield" (one suspects Minneapolis or Milwaukee), she focuses on a few dozen children between the ages of ten and thirteen; old enough to understand some of what goes on in the country,

but still firming up their opinions. All of them come from upper-middle-class or cushier social backgrounds. Hagerman wants to find out how they think about race, and where their ideas come from.

We can reject, nearly out of hand, the idea that they come directly from their parents. As anyone who has spent time with children knows, the transmission of ideas doesn't work that neatly, and Hagerman considers and dismisses the idea early in the book. Instead, we are treated to a stroll through the gestalt of privileged white life. Like Hagerman, we spend time with the kids, their extracurricular activities, their relationships with their parents, said parents' relationships with their real-estate values and school choices, on and on.

Many works of social science, being less narrative than, say, works of history, wind up recapitulating, perhaps unconsciously, narrative structures with deep roots in the language. In the case of White Kids, we have a tale of three neighborhoods, not unlike 
the Three Bears of Goldilocks fame. There's suburban conservative "Sheridan," moderate semi-urban "Wheaton Hills," and funky gentrifying "Evergreen." All three are highly privileged spaces, and Hagerman does not spare Evergreen her criticisms. The parents there, just as parents in Sheridan, seek to reproduce their advantages for their children; they just do so through hiring private tutors and enrichment experiences for their little darlings rather than removing them from Petersfield's public schools.

That being said, a lot of the differences in terms of understanding of race between the kids on display seem to come down to the neighborhood, in the end. Sheridan kids see almost no people of color and believe that racism is a thing of the past and negative outcomes for people of color as generally those people's own fault. Wheaton Hills kids acknowledge that racism is a thing but do little about it. Evergreen kids are a little closer to grasping the concept of structural racism and occasionally do something volunteering or protesting - to fight it. We have a preference between the three bears, and it's not in-the-middle Wheaton Hills this time. Whether the young of any of the above neighborhoods will be willing to surrender some of their privilege - the ultimate, though somewhat vague, move of white antiracism in Hagerman's book - to make a fairer America remains to be seen.

White Kids frequently refers to the dilemma of privilege: other than some oblivious Sheridanites, most of the parents and the kids understand racism is a problem and that they have privileges others, especially people of color, do not . . . but they don't see how they can ethically refuse to give their kids every advantage to succeed in life.

This dilemma is deeply structured by the United States' political economy. Or, to put it in less academic terms: losing class status sucks, hard. Given the ghoulish spectrum of bad fates that await those who slip down the socioeconomic ladder, it's not just a matter of reproducing people similar to themselves that drives white parents to cling to their privileges. It's rough out there and people will use any edge they can to hold on. Appealing to morality and racial fair play in this situation is akin to calling on the rules in a knife fight.

The worst and least understandable behavior of the relatively enlightened parents in this book - putting aside the Sheridanites and their thinly veiled racism - is the refusal to extend the idea that Black kids are as innocent and worthy of every advantage as the white kids they raise. This is the internalization of capitalism's imperative of Thatcher's dictum that "there is no such thing as society, only men, women and families." This, more than a refusal to extend their kids' help and 
opportunities, is the crux of the problem. If they truly took on board the idea that all kids deserve the same chances, they wouldn't be reducing the opportunities for their kids, making them sit at home rather than do extracurriculars or some such thing. They would be looking to tear down a system that guarantees these inequities in every aspect of its construction to replace it with something better. They'd be looking to get cops out of schools and replace them with counselors. They'd be looking to decouple school funding from real-estate values. Ultimately, they'd be looking to end the system of racialized capitalism that relies on invidious racial differences to function.

Hagerman, like other liberal antiracist social scientists, insists on the structural-ness of racism, and, indeed, implicitly grades the enlightenment of her subjects (or, mostly, their parents) on how much they grasp that racism is both real and not a matter solely of individual affect. But in the end, it's individual decision-making on the part of privileged parents that she emphasizes in terms of making things better. To be fair, this is probably not the main point of the book, as a work of sociology; that would be the insights into racialized socialization she provides through keen observation of the kids and parents. But for non-sociologist readers - and it seems that White Kids is gaining a respectable popular audience for an academic social science text - the takeaway will be what to do with the dilemma of privilege, and here Hagerman does not provide a structural answer, but an individualistic one.

Peter Berard, Ph.D., is a writer, historian and organizer living in Watertown, Mass. He is the Book Review Editor for San Antonio Review. Read more of his work at Too Much Berard. 